\title{
Functional and nutritional properties of mango stone kernel flour
}

\author{
- P. N. Patil, S. P. Sonawane and S.P. Divekar ${ }^{1 *}$ \\ Department of Agricultural Process Engineering, College of Agriculture, Dr. Balasaheb Sawant Konkan Krishi Vidyapeeth, Dapoli \\ (M.S.) India \\ ${ }^{1}$ Agricultural Engineering Section, College of Agriculture, Dr. Panjabrao Deshmukh Krishi Vidyapeeth, Akola (M.S.) India \\ Email : santosh.divekar75@gmail.com \\ *Author for Correspondence \\ Research chronicle : Received : 18.10.2019; Revised : 04.05.2020; Accepted : 18.05 .2020
}

SUMMARY :

Worldwide production is mostly concentrated in Asia, accounting for 75 per cent. India is the largest producer of mango followed by China (4.3 Million MT), Thailand (2.6 Million MT) and Indonesia (2.13 Million MT). During the year 2013-14, the area under mango in India was 2516 thousand ha. With production of 18431.3 thousand MT and productivity was 7.3 MT/ha. After consumption or industrial processing of mangoes, approximately 40 to 60 per cent waste is generated during processing of mangoes; 12 to 15 per cent consists of peels and 15 to 20 per cent of kernels. According to mango varieties, the seed represents from 10 to 25 per cent of the whole fruit weight. The kernel inside the seed represents from 45 to 75 per cent of the seed and about 20 per cent of the whole fruit (Karunanithi et al., 2015). After processing of mango fruits, the by-product available is peel and seed. The mango seed has oil and other nutritive content. It is an important source of sugars and minerals. The deoiled mango seed flour can be used further for preparation of value-added products. Mango seed kernels contain on an average 6.0 per cent protein, 11 per cent fat, 77 per cent carbohydrate, 2.0 per cent crude fibre and 2.0 per cent ash. Mango seed kernels were shown to be a good source of polyphenols, phytosterols as campesterol, $\beta$-sitosterol and tocopherols. The functionl properties include bulk density, oil absorption capacity, water absorption capacity and wettability. The properties such as moisture, protein, fat, carbohydrate and energy are included in nutritional properties.

KEY WORDS : Mango seed kernel flour, Functional properties, Nutritional properties

How to cite this paper : Patil, P.N., Sonawane, S.P. and Divekar, S.P. (2020). Functional and nutritional properties of mango stone kernel flour. Internat. J. Proc. \& Post Harvest Technol., 11(1) : 1-6. DOI: 10. 15740/ HAS/IJPPHT/11.1/1-6. Copyright@ 2020: Hind Agri-Horticultural Society. 